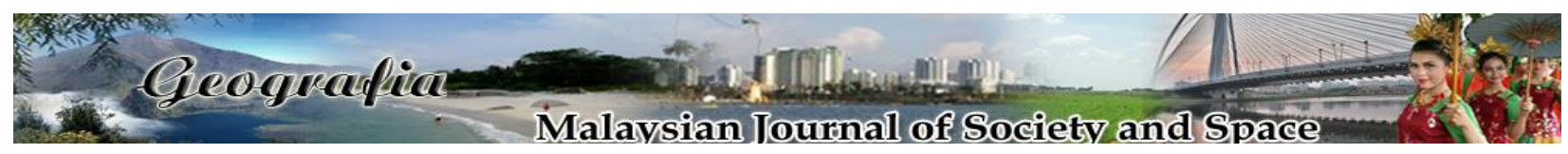

\title{
Pandangan guru dan murid terhadap pengaplikasian Story Map GIS dalam mata pelajaran Sejarah STPM
}

\author{
Shuhaida Abdul Malek ${ }^{1}$, Mokhtar Jaafar ${ }^{1}$, Kadaruddin Aiyub ${ }^{1}$ \\ Program Geografi, Pusat Pembangunan, Sosial dan Persekitaran, \\ Fakulti Sains Sosial dan Kemanusiaan, Universiti Kebangsaan Malaysia \\ Correspondence: Mokhtar bin Jaafar (email: m_jaafar@ukm.edu.my)
}

Received: 22 May 2019; Accepted: 20 September 2019; Published: 25 November 2019

\begin{abstract}
Abstrak
Mata pelajaran sejarah dianggap mata pelajaran yang membosankan dalam kalangan murid. Ini berlaku kerana kaedah pengajaran yang digunakan oleh guru tidak dapat menarik minat murid untuk mempelajari mata pelajaran tersebut. Kaedah 'chalk and talk' rata-rata masih diamalkan di kebanyakan sekolah dan murid menghafal fakta Sejarah semata-semata untuk dimuntahkan semasa peperiksaan dijalankan. Kajian ini bertujuan untuk meneroka persepsi guru dan murid terhadap pengaplikasian Story Map GIS dalam mata pelajaran Sejarah. Kajian ini merupakan sebuah kajian kualitatif yang melibatkan tiga orang guru dan 30 orang murid tingkatan enam sebagai informan di tiga buah sekolah. Temu bual mendalam telah dijalankan terhadap tiga orang guru tersebut dan temu bual kumpulan berfokus dijalankan terhadap murid-murid yang dibahagikan kepada enam kumpulan. Selain itu, pengkaji turut membuat pemerhatian dan menjalankan analisis dokumen terhadap hasil kerja Story Map GIS murid. Pengumpulan data dibuat dalam tiga fasa iaitu fasa perbengkelan, fasa pembentangan dan ketika temu bual dijalankan. Pengkaji telah menjalankan analisis tematik bagi menjawab persoalan kajian menggunakan aplikasi ATLAS.ti. Hasil kajian ini mendapati majoriti guru dan murid-murid mempunyai persepsi yang positif terhadap pengaplikasian Story Map GIS dalam mata pelajaran Sejarah STPM. Aplikasi Story Map GIS sesuai untuk diaplikasi di peringkat menengah dan dapat menarik perhatian murid terhadap mata pelajaran Sejarah. Pengenalan terhadap aplikasi Story Map GIS dalam mata pelajaran sejarah dapat menarik minat murid terhadap pembelajaran sejarah dan pada masa yang sama memperkenalkan konsep ruang kepada mereka.
\end{abstract}

Kata kunci: GIS, mata pelajaran Sejarah, pandangan, penceritaan, Story Map, STPM 


\title{
Teachers and students view toward the aplication of Story Map GIS in STPM History subject
}

\begin{abstract}
History is normally considered as an unpopular subject among students. This is because the teaching method used by the teacher does not attract the students to learn the subject. The common chalk and talk method is still being practiced in most schools and students tend to memorize history facts solely for the purpose of regurgitating during examination. This study aims to explore teachers and student's perceptions on the application of Story Map GIS in History. It is a qualitative study involving three teachers and 30 sixth graders as participants in three schools. In-depth interviews were conducted with the three teachers and followed by student's focus group interviews that was divided into six groups. In addition, the researcher conducted observation and a document analysis on student's work on Story Map GIS. The data collection is done in three phases: workshop phase, presentation phase and while the interview was conducted. The researcher conducted a thematic analysis to answer the research question using the ATLAS.ti application. The results show majority of the teachers and students have positive perceptions on applying Story Map GIS in STPM History subject. Furthermore, the application of Story Map GIS is appropriate to be applied in secondary school and captures student's interest in the subject of History. In conclusion, introduction of Story Map GIS application in history subject can attract student's attention to learn history and concurrently introduce them to the concept of space.
\end{abstract}

Keywords: GIS, history subject, perception, story telling, story map, STPM

\section{Pengenalan}

Penceritaan merupakan suatu kaedah yang telah lama diguna pakai dalam menyampaikan ilmu pengetahuan. Ia sangat sesuai untuk menyampaikan sesuatu kepada audien secara terus (Kirkby et al., 2014). Kaedah penceritaan telah diamalkan sejak lebih 200,000 tahun dahulu apabila dinding-dinding gua dilukis dengan gambar dan simbol untuk menceritakan sesuatu peristiwa. Ini dapat kita lihat sewaktu zaman pemerintahan Firaun, apabila dinding-dinding piramid dilukis untuk menceritakan tentang sistem pemerintahan Firaun dan konsep ketuhanan pada zaman tersebut (Magli, 2017). Bukan sahaja di Timur Tengah, malah masyarakat Melayu Nusantara juga sangat sinonim dengan kaedah penceritaan dalam menyampaikan sesuatu maklumat dari suatu generasi ke suatu generasi (Tjandra et al., 2017). Ini disahkan oleh Ayu (2018) yang menyatakan bahawa sastera lisan merupakan suatu amalan yang menjadi budaya masyarakat Nusantara. Manusia seluruh dunia umumnya menggunakan kaedah penceritaan sebagai suatu alat penyampaian yang berkesan dalam pelbagai aspek seperti aspek nilai budaya, kepercayaan dan sejarah kepada generasi seterusnya sebagaimana sejarah Melayu yang dinukilkan dalam Hikayat Hang Tuah, Hikayat Merong Mahawangsa, Hikayat Inderapura, dan Salalatus Salatin yang ditulis oleh Tun Sri Lanang, seorang pembesar Melayu sekitar tahun 1614 yang menjadi rujukan sejarah Melayu sehingga kini. 
Sehingga kini, teknik penceritaan masih lagi relevan sebagai kaedah yang mampu menarik perhatian audien kerana perkataan dan aksi pencerita adalah alat yang boleh menggalakkan daya imaginasi pendengar cerita. Malah konsep ini menjadi lebih menarik dan mudah kerana pencerita dan pendengar mempunyai hubungan yang akrab dan mempunyai ikatan yang kuat di antara satu sama lain (Wayne, 1978).

Kaedah penceritaan masih lagi diamalkan di sekolah-sekolah dan merupakan salah satu kaedah berkesan bagi menyampaikan ilmu kepada murid-murid di sekolah. Bagi memastikan teknik penceritaan ini bukan sahaja berkesan kepada murid malah dapat mewujudkan perasaan seronok kepada mereka, guru perlu membuat persiapan yang rapi sesuai dengan tahap muridmurid tersebut serta dapat menyediakan bahan penceritaan yang menarik perhatian mereka dan kaedah penceritaan yang sesuai dengan zamannya.

Generasi kini yang sangat terikat dengan teknologi maklumat memerlukan kaedah pembelajaran yang menarik perhatian mereka dengan memperkenalkan pembelajaran yang menggunakan teknologi maklumat. Bermula daripada Generasi Y sehinggalah generasi Alpha, mereka membesar dengan teknologi yang tinggi dan sangat terikat dengan internet (Tapscott, 2008). Sejajar dengan itu, teknik penceritaan pada masa kini juga telah mula digabungkan dengan kaedah baru yang menarik audien dengan menggunakan teknologi terkini yang sangat sesuai digunakan untuk generasi kini. Persembahan grafik, gambar, audio dan video disediakan bagi membentuk penceritaan yang menarik. Penceritaannya pula meluas daripada peristiwa sejarah, topik sains yang spesifik, aktiviti semasa, kehidupan harian dapat digunakan dengan kaedah ini. Penggunaan aplikasi sebagai salah alat penceritaan adalah pilihan yang sesuai pada masa kini.

Story Map GIS merupakan sebuah aplikasi yang dibangunkan oleh ESRI (Environmental Systems Research Institute) yang mengabung jalin pemetaan dan penceritaan dalam satu masa. Perkara yang menarik berkaitan pengaplikasian Story Map GIS adalah ia boleh memetakan sebarang tema yang dapat dikongsikan ke seluruh dunia serta mesra pengguna (Marta \& Osso, 2015). Naratif menggunakan aplikasi merupakan penceritaan melangkaui kemampuan manusia (Dahlstrom, 2014). Penceritaannya meluas merentasi sempadan ruang kerana ia menggunakan teknologi jaringan internet yang dapat dikongsi ke seluruh dunia. Kajian ini bertujuan mengkaji persepsi murid dan guru iaitu dua entiti penting di sekolah terhadap pengaplikasi Story Map GIS dalam mata pelajaran Sejarah bagi tujuan peningkatan minat murid terhadap mata pelajaran tersebut.

\section{Story Map GIS dan Penceritaan}

Story Map GIS merupakan salah satu cabang Sistem Maklumat Geografi (GIS). GIS adalah aplikasi sistem maklumat yang digunakan untuk menyimpan, memapar, menganalisis dan memanipulasi data yang berkaitan dengan ruangan atau spatial dengan pemetaan (Lateh \& Muniandy, 2011). GIS berkemampuan untuk melakukan aktiviti penerokaan data dengan alat visual interaktif dan dinamik yang berkaitan (Ang, 2015). Pemetaan dapat menginterpretasikan pelbagai jenis cerita, malah peta telah bercerita untuk suatu jangka masa yang panjang lebih seabad untuk kegunaan manusia. Peta dapat menarik perhatian manusia, merangsang imaginasi dan memberi inspirasi kepada manusia (Kerski, 2013). Peta berperanan sebagai sebuah cerita bagi pengembaraan pendakwah-pendakwah zaman silam, penaklukan-penaklukan kuasa-kuasa besar dan perdagangan yang dijalankan di antara benua. Peta penting bagi merungkai sejarah 
silam untuk dikongsi dengan generasi pada masa kini. Pemetaan ini menarik perhatian pembikinpembikin filem untuk memaparkan naratif perjalanan tokoh-tokoh tersohor dan peristiwaperistiwa sejarah dunia melalui filem-filem mereka, ia mendapat sambutan yang baik daripada penonton. Antara filem yang memetakan naratif rentetan sejarah melalui pemetaan adalah seperti filem Ghandi (1982), Leftenan Adnan (2000), The Bomb (2015) dan The Opium War (1997) yang memaparkan pergerakan cerita dari suatu lokasi kepada suatu lokasi yang lain.

\section{Aplikasi Story Map GIS}

Story Map GIS yang dibangunkan oleh ESRI merupakan suatu platform yang sesuai digunakan oleh pelbagai peringkat umur untuk meneroka Sistem Maklumat Geografi (GIS) dengan lebih mudah walaupun seseorang individu tidak mempunyai latar belakang pendidikan berkaitan GIS. ESRI telah membangunkan 11 template yang boleh digunakan oleh pengguna bagi mencipta suatu penceritaan menggunakan peta. Story Map GIS disertakan bersama-sama dengan unit lain yang dapat membantu penceritaan yang dibuat menggunakan Story Map GIS. Ia bukan sekadar pemetaan yang diintegrasikan dengan lagenda peta, malah turut boleh dimasukkan teks, gambar dan video serta menyediakan kemudahan meleret (swipe), tetingkap (pop-ups) dan gelangsar masa (time slider). Aplikasi ini boleh diperoleh secara percuma sebanyak dua giga byte dan sekiranya pengguna memerlukan lebih daripada dua giga byte, pengguna boleh melanggan daripada ESRI (Battersby \& Remington, 2013).

\section{Story Map GIS sebagai Bahan Bantu Mengajar (BBM)}

Beberapa kajian telah dijalankan berkaitan aplikasi Story Map GIS. Antaranya, kajian dijalankan oleh Marta dan Osso (2015) yang mendapati guru-guru dan murid-murid sangat berminat menggunakan Story Map GIS sebagai bahan bantu belajar mereka. Penceritaan menggunakan peta memberi motivasi kepada murid. Mereka beranggapan bahawa penggunaan aplikasi Story Map GIS merupakan suatu aktiviti yang menarik yang dapat memanipulasi kemahiran inkuiri mereka. Ia membantu murid untuk membangunkan tingkah laku yang positif terhadap proses pembelajaran. Melalui aktiviti bercerita murid secara langsung mendapat pengalaman menghubungkan sesuatu plot-plot cerita menjadi sebuah naratif lengkap dan secara langsung mencipta hubungan bermakna antara komuniti yang mendengar ceritanya (Coskie, et al., 2010). Tambah Marta dan Osso lagi, Story Map GIS adalah alat penceritaan berbantukan peta yang memberi peluang untuk mempromosi imaginasi murid dan imaginasi ini membantu murid menyelesaikan masalah dan berfikir di luar kotak.

Selain itu, dapatan kajian Cope et al. (2018) juga sejajar dengan dapatan kajian Marta dan Osso, di mana Story Map GIS didapati berjaya menarik minat guru dan murid. Walau bagaimanapun, tambah Cope et al. (2018) lagi, Story Map GIS tidak boleh berfungsi bagi menggantikan peranan buku teks, kaedah pembelajaran kajian lapangan atau aktiviti makmal tetapi ia dapat menyediakan 'augmented reality experience' yang dapat meningkatkan pembelajaran. Pengajaran dan pembelajaran (PdP) yang disertakan kemudahan penceritaan menggunakan pemetaan akan menggalakkan imaginasi dan murid akan lebih kreatif dalam menyelesaikan masalah. Beliau telah membangunkan kaedah menilai Story Map GIS bagi tujuan pendidikan bagi mata pelajaran geografi dengan menggunakan lima prinsip asas yang telah direka oleh pihak ESRI sebagai panduan. Edmondson (2018) pula melengkapkan kajian Cope et al. (2018) dengan membangunkan suatu Rancangan Mengajar menggunakan Story Map GIS 
yang boleh menjadi rujukan para guru bagi mata pelajaran Geografi. Hasil kajian Kallaher dan Gamble (2017) mendapati semua responden yang terdiri daripada murid-murid sekolah sangat berkeyakinan dalam membina peta menggunakan Story Map GIS dan mereka juga berpendapat bahawa Story Map GIS sangat membantu pembelajaran mereka.

Kajian Strachan (2014) pula menunjukkan bahawa guru menganggap Story Map GIS merupakan suatu aplikasi yang mesra pengguna, interaktif dan dapat menghubungkan murid dengan dunia luar. Responden kajiannya iaitu guru merasakan bahawa murid-muridnya seronok menggunakan aplikasi Story Map GIS dan mereka mampu mencipta Story Map GIS mereka sendiri bagi tujuan PdP. Mereka percaya bahawa Story Map GIS dapat digunakan sebagai bahan untuk ditayangkan yang memenuhi kehendak piawaian akademik dan sesuai bagi kegunaan pelbagai mata pelajaran atau bidang. Selain itu, Berendsen et al. (2018) menjelaskan bahawa Story Map GIS dapat menyediakan peta dalam pelbagai saiz, sama ada di peringkat tempatan, negeri, wilayah, negara mahupun dunia. Ini membolehkan murid meneroka dunia secara langsung selain menyelesaikan tuntutan tugasan yang diberikan. Selain itu, menurut beliau lagi Story Map GIS juga mudah untuk ditambah baik berbanding peta manual yang sukar untuk diubah dan memerlukan kos yang lebih tinggi jika berlaku sebarang perubahan. Murid juga berupaya untuk mencipta Story Map GIS mereka sendiri kerana ia mesra pengguna.

Sejajar dengan dapatan pengkaji-pengkaji sebelum ini, Kerski (2013) berpandangan bahawa penggunaan peta di sekolah amatlah penting bagi semua mata pelajaran yang menitik beratkan tentang lokasi dalam mata pelajaran tersebut bagi mengukuhkan pemahaman murid dan peta juga amat sesuai bagi kaedah pembelajaran berdasarkan masalah (problem-based learning).

Melalui kajian-kajian lepas berkaitan aplikasi Story Map GIS dapat disimpulkan bahawa aplikasi ini merupakan suatu aplikasi yang mesra pengguna, sangat membantu dalam pembelajaran, dapat mengasah Kemahiran Berfikir Aras Tinggi (KBAT) yang menggalakkan murid berfikir di luar kotak dalam menyelesaikan permasalahan. Story Map GIS juga dapat menerbitkan keyakinan kepada murid dalam pelajaran mereka dan sesuai untuk semua mata pelajaran yang berkaitan dengan lokasi. Tuntasnya, Story Map GIS merupakan aplikasi yang sesuai untuk diguna pakai bagi tujuan pendidikan sebagai mana perbincangan sebelum ini yang melibatkan pengajaran dan pembelajaran berasaskan pemetaan. Manakala, pengintegrasian Story Map GIS dengan mata pelajaran Sejarah juga dianggap secocok dan mampu menarik minat murid generasi kini yang mempunyai kadar literasi Teknologi Maklumat dan Komunikasi (TMK) yang tinggi jika dibandingkan dengan generasi terdahulu. Murid berpeluang mengeksplorasi Story Map GIS dengan memetakan sendiri sejarah yang dipelajari yang secara langsung memupuk KBAT semasa menggunakan aplikasi ini.

Kajian ini dijalankan berlandaskan teori "Learning by doing" yang telah diilhamkan oleh Dewey (1933). Menurut Dewey, murid akan dapat mempelajari sesuatu menerusi aktiviti yang mereka lakukan. Di dalam kajian ini murid-murid diminta untuk membina sebuah peta sejarah berkaitan tokoh penentangan kuasa-kuasa asing di Tanah Melayu, Sabah, Sarawak, Myanmar dan Indonesia menggunakan aplikasi Story Map GIS. Murid di bahagikan kepada kumpulan bagi menjalankan tugasan ini. Murid-murid mengenal pasti lokasi berlakunya peristiwa sejarah, memplotkan peta lokasi tersebut, memasukkan maklumat atau data berkaitan sejarah peristiwa tersebut dan memasukkan unsur-unsur gambar dan video bagi mengukuhkan lagi penceritaan di dalam Story Map GIS mereka. 


\section{Kaedah penyelidikan}

Kajian ini merupakan sebuah kajian kes yang menggunakan kaedah kualitatif dalam menganalisis data yang diperoleh. Sampel kajian terdiri daripada tiga orang guru sejarah yang berpengalaman lebih daripada lima tahun dan 30 orang murid tingkatan 6 yang mengambil mata pelajaran sejarah dalam peperiksaan Sijil Tinggi Pelajaran Malaysia (STPM) bagi tahun $2017 / 2018$.

Informan murid diberikan tugasan untuk memetaan kronologi peristiwa penentangan tokohtokoh penentangan kuasa asing di Tanah Melayu, Sabah, Sarawak, Myanmar serta Indonesia menggunakan aplikasi Story Map GIS dan hasil pemetaan tersebut dibentangkan di hadapan kelas bagi tujuan perbincangan hasil tugasan murid.

Kaedah pemerolehan data dibuat melalui temu bual mendalam yang dijalankan terhadap informan guru dan temu bual kumpulan berfokus kepada murid-murid, pengkaji turut menjalankan prosedur pemerhatian terhadap tingkah laku murid yang dicatatkan semasa mereka menjalankan aktiviti mereka cipta peta Story Map GIS mereka di dalam nota lapangan. Item di bawah adalah antara soalan yang dibangunkan bagi memperoleh pandangan guru dan murid berkaitan aplikasi Story Map GIS.

\section{Item temu bual informan guru}

1. Apakah pandangan cikgu berkaitan aplikasi Story Map GIS?

2. Adakah aplikasi ini sesuai untuk digunakan sebagai bahan bantu mengajar (BBM) bagi mata pelajaran Sejarah?

3. Pada pandangan cikgu adakah murid berminat mengaplikasikan Story Map GIS?

4. Adakah murid cikgu berkeupayaan untuk mengaplikasikan Story Map GIS?

\section{Item temu bual kumpulan berfokus murid}

1. Pernah kalian menggunakan aplikasi Story Map GIS sebelum ini?

2. Apakah perasaan kalian ketika menggunakan aplikasi ini?

3. Pada pandangan kalian, adakah Story Map GIS membantu PdP Sejarah kalian?

4. Adakah aplikasi Story Map GIS mesra pengguna?

Data daripada analisis dokumen, temu bual individu, temu bual kumpulan berfokus serta pemerhatian seperti yang terdapat di dalam jadual 1 dianalisis menggunakan kaedah tematik. Tema-tema dikeluarkan melalui skrip-skrip temu bual, nota-nota lapangan dan hasil kerja murid untuk mengetahui persepsi mereka terhadap aplikasi Story Map GIS.

Jadual 1. Kaedah Pengumpulan Data

\begin{tabular}{lcccc}
\hline \multicolumn{1}{c}{ Kaedah Pengumpulan Data } & Sekolah A & Sekolah B & Sekolah C & Jumlah \\
\hline Analisis Dokumen & 3 & 3 & 3 & 9 \\
$\begin{array}{l}\text { Temu bual kumpulan berfokus } \\
\text { (murid) }\end{array}$ & 2 & 2 & 2 & 6 \\
$\begin{array}{l}\text { Temu bual individu (guru) } \\
\text { Pemerhatian }\end{array}$ & 1 & 1 & 1 & 3 \\
\hline
\end{tabular}


Kajian ini dijalankan di tiga buah sekolah di Negeri Sembilan. Ketiga-tiga sekolah ini menawarkan mata pelajaran Sejarah di peringkat STPM. Pemilihan sekolah berdasarkan keputusan mata pelajaran Sejarah STPM bagi dua tahun berturut-turut iaitu 2016 dan 2017 yang hampir setara di antara ketiga-tiga sekolah yang dipilih (Rujuk Jadual 2). Ketiga-tiga sekolah dikategorikan sebagai sekolah yang mempunyai pencapaian sederhana dalam mata pelajaran Sejarah STPM.

Jadual 2. Analisis Keputusan Kertas Sejarah STPM 2016/2018

\begin{tabular}{lllll}
\hline Bil & Sekolah & Tahun & Lulus Penuh & NGMP \\
\hline 1. & Sekolah A (Kes 1) & 2016 & 82.4 & 2.40 \\
& & 2017 & 96.6 & 2.71 \\
2. & Sekolah B (KES 2) & 2016 & 85.7 & 2.45 \\
& & 2017 & 86.7 & 2.40 \\
3. & Sekolah C (KES 3) & 2016 & 90.0 & 2.73 \\
& & 2017 & 94.4 & 2.75 \\
\hline
\end{tabular}

\section{Hasil kajian dan perbincangan}

\section{a. Demografi responden}

Tiga temu bual mendalam telah dijalankan kepada tiga orang guru Sejarah Tingkatan 6 daripada tiga buah sekolah berbeza yang menawarkan kelas Tingkatan 6 di sekolah mereka. Guru tersebut terdiri daripada seorang guru lelaki dan dua orang guru perempuan. Kesemua guru ini telah mengajar mata pelajaran Sejarah melebihi lima tahun. Semua guru tersebut merupakan guru opsyen sejarah. Manakala seramai 30 orang murid Tingkatan 6 terlibat dalam kajian ini yang di temu bual melalui kaedah kumpulan berfokus. Sebanyak enam kumpulan murid dan di setiap sekolah terdapat dua kumpulan murid di temu bual. Seramai sembilan orang murid lelaki dan 21 murid perempuan terlibat dalam kajian ini. Di sekolah A, seramai tujuh orang murid perempuan dan tiga orang murid lelaki terlibat. Majoriti murid-murid tersebut tinggal di asrama dan hanya dua orang murid tinggal bersama ibu bapa mereka. Di sekolah B juga terdapat tujuh orang murid perempuan dan tiga murid lelaki terlibat tetapi majoriti daripada mereka tinggal di rumah keluarga masing-masing, hanya tiga orang murid tinggal di asrama. Seterusnya di sekolah $\mathrm{C}$, majoriti murid yang terdiri daripada lapan orang murid perempuan dan dua orang murid lelaki. Seramai tiga orang tinggal di asrama dan majoriti yang lain tinggal di rumah keluarga masing-masing.

b. Pandangan murid dan guru terhadap penggunaan Story Map GIS dalam mata pelajaran Sejarah

Rajah 1 merupakan rajah dapatan bagi tema pandangan guru dan murid terhadap pengaplikasian Story Map GIS dalam mata pelajaran Sejarah Tingkatan 6. Bagi tema persepsi guru dan murid terbahagi kepada dua bahagian iaitu bahagian pertama, persepsi terhadap fizikal Story Map GIS dan bahagian kedua, persepsi berkaitan emosi murid ketika menggunakan Story Map GIS. Bahagian emosi terbahagi kepada dua pecahan iaitu emosi negatif dan emosi positif. 


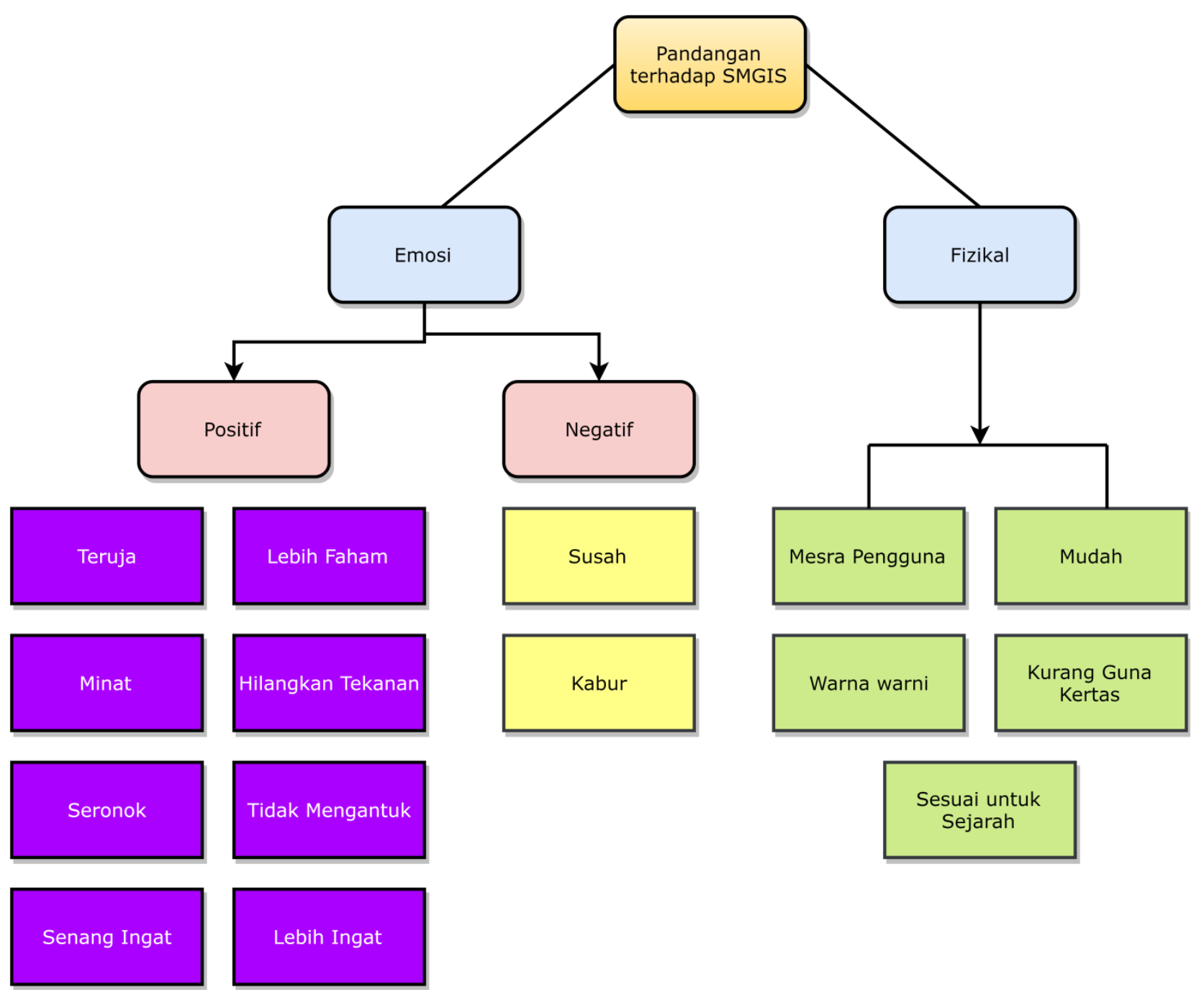

Rajah 1. Tema pandangan murid dan guru terhadap Story Map GIS

\section{i. Aspek fizikal}

Pengkaji mendapati dalam aspek fizikal, menurut informan murid, Story Map GIS dikatakan sebagai suatu aplikasi yang mesra pengguna selain itu, perisian ini sistematik dan mudah untuk digunakan walaupun tidak mempunyai latar belakang kemahiran mengendali Sistem Maklumat Geografi (GIS). Hasil temu bual kumpulan berfokus terhadap ketiga-tiga kes, didapati bahawa Story Map GIS merupakan sebuah aplikasi yang mesra pengguna. Terdapat beberapa faktor yang diketengahkan oleh informan berkaitan mesra pengguna antaranya adalah kerana ia memudahkan pengguna untuk mencari data di dalam satu laman web sahaja. Mereka juga berpendapat Story Map GIS sebuah aplikasi yang mudah digunakan dan difahami serta boleh digunakan pada bilabila masa serta di pelbagai lokasi.

"Story Map GIS merupakan suatu perisian yang mesra pengguna kerana ia memudahkan pengguna untuk mencari data dalam satu laman web sahaja" Informan A 
"Story Map GIS mesra pengguna" Informan B

"Ya, Story Map GIS mesra pengguna kerana mudah digunakan dan difahami serta boleh digunakan pada bila-bila masa dan di mana jua" Informan C.

Kumpulan Wawancara Berfokus B

Story Map GIS juga dianggap mesra pengguna kerana ia memudahkan untuk pelayar atau audien Story Map GIS menggunakannya sama ada bagi memperoleh maklumat, gambar atau peta lokasi sesuatu tempat serta boleh digunakan oleh pelbagai peringkat umur.

"Ya, kerana pada pandangan saya Story Map GIS sangat memudahkan pengguna dalam menggunakannya sama ada memperoleh maklumat gambar dan peta" Informan D

"Ya, sebab Story Map banyak maklumat dan boleh digunakan oleh semua orang tanpa mengira peringkat umur" Informan E

Kumpulan Wawancara Berfokus B

"Lebih mudah belajar" Informan E.

"Seronok, senang" Infoman I.

"Ada warna-warna, lebih faham, ada visual" Informan E

Kumpulan Wawancara Berfokus B

Penggunaan aplikasi ini juga dapat mengurangkan penggunaan kertas kerana Story Map GIS menyediakan platform bagi pengguna memaparkan peta yang boleh diplot serta terdapat ruang untuk penceritaan terhadap peta yang dipaparkan. Penceritaan tersebut juga diperkukuhkan dengan memasukkan video dan gambar berkaitan. Memaparkan peta secara amalan mencintai alam sekitar dengan mengamalkan konsep 'paperless'. Manual memerlukan penggunaan kertas yang bersaiz lebar, selain perlu juga menggunakan kertas yang banyak bagi tujuan penerangan cerita berkaitan peta dan gambar-gambar yang menyokong cerita tersebut. Memaparkan peta secara digital merupakan amalan mencintai alam sekitar dengan mengamalkan konsep 'paperless'.

"Penggunaan Story Map GIS sebenarnya dapat mengurangkan penggunaan kertas, tidak perlu melukis peta secara fizikal, maklumat berkaitan peta atau gambar berkaitan cerita yang diterangkan, semua tertera di muka Story Map GIS" Informan J

\section{Kumpulan Wawancara Kumpulan Wawancara Berfokus A}

Aplikasi Story Map GIS dikatakan sesuai bagi mata pelajaran Sejarah. Ini kerana Story Map GIS dapat menunjukkan lokasi berlakunya sesuatu peristiwa sejarah. Story Map GIS juga turut menyediakan ruang penceritaan yang melengkapkan pemaparan peta tersebut bagi tujuan penerangan sama ada berkaitan kronologi peristiwa atau kronologi tarikh peristiwa itu berlaku. Menurut seorang guru, Story Map GIS dapat memberi kefahaman kepada murid terhadap kronologi peristiwa sejarah dengan baik. Pendapat ini juga disokong oleh beberapa murid yang 
menyatakan bahawa Story Map GIS sesuai untuk mata pelajaran Sejarah kerana penggunaannya dapat mengingatkan murid terhadap peristiwa sejarah dengan input pelbagai seperti peta, maklumat sejarah, gambar dan video berkaitan. Murid bukan sahaja dapat faham kronologi sejarah malah mereka dapat mengingat peristiwa atau fakta sejarah tersebut kerana mereka dapat membuat imaginasi melalui video, gambar dan teks yang dipaparkan oleh Story Map GIS. Seorang lagi informan membandingkan kaedah pembelajaran sejarah yang dahulu iaitu dengan hanya merujuk teks, Story Map GIS adalah lebih baik kerana dapat divisualisasikan.

"Sesuai untuk belajar sejarah” Informan I

"Lebih faham sejarah. Kalau kita belajar baca je kita tak faham. Kalau kita guna Story

Map GIS, kita boleh ingat fakta lebih baik. Boleh tengok video yang ada” Informan B

“Kita boleh 'imagine’ sejarah kalau guna Story Map GIS” Informan D

Kumpulan Wawancara Berfokus B

\begin{abstract}
"Rasa membantu terutama kalau belajar berkaitan peristiwa" Informan K
"Kalau berkaitan peristiwa, kronologi rasanya membantu" Infoman G

"Senang nak ingat sebab visual. Kalau dulu tulisan je tapi sekarang ada visual"

Informan L.

“Kalau peristiwa dan kronologi sesuai lah” Informan F
\end{abstract}

Kumpulan Wawancara Berfokus C

Dapatan ini sama sebagaimana yang diuar-uarkan oleh pihak syarikat pengeluar aplikasi ini, ESRI. Menurut ESRI, aplikasi ini dibangunkan bagi menjadi platform bagi sesiapapun untuk meneroka Sistem Maklumat Geografi (GIS) dengan lebih mudah walaupun tidak mempunyai latar belakang berkaitan GIS (Cope et al., 2018; Warshawsky, 2016). Ia juga sesuai untuk penggunaan bagi mata pelajaran Sejarah konsisten dengan dapatan oleh Marta dan Osso (2015).

\title{
i. $\quad$ Aspek emosi (positif)
}

Manakala bahagian kedua bagi tema persepsi terhadap Story Map GIS pula adalah persepsi emosi murid ketika mengaplikasi Story Map GIS. Informan J menyatakan bahawa Story Map GIS dapat menghilangkan tekanan kerana murid berminat dengan aktiviti yang melibatkan TMK dan ini sebenarnya sekali gus menghilangkan rasa bosan ketika sesi PdP berbanding kaedah PdP biasa yang hanya berbantukan kertas. Penggunaan aplikasi ini juga dianggap menarik kerana pembelajaran sejarah menggunakan peta yang interaktif.

"Boleh hilangkan stress dengan memetakan sejarah guna Story Map GIS, boleh tengok video, tak lah bosan, asyik guna kertas je sekarang, ada peta lebih menarik." Infoman J. 
Bukan murid sahaja yang berminat malah guru juga turut berminat untuk mempelajari aplikasi Ini dapat dilihat melalui temu bual bersama Informan Cikgu $\mathrm{MH}$ di sekolah B. Menurut Cikgu MH bukan murid sahaja berminat malah beliau sendiri turut berminat terhadap aplikasi Story Map GIS.

"Pada pandangan saya bukan murid sahaja berminat terhadap Story Map GIS, cikgu pun turut berminat untuk tahu lebih mendalam aplikasi ni” Informan Guru MH.

Seorang lagi Informan Guru iaitu Cikgu AR menyokong 200 peratus terhadap pengaplikasi Story Map GIS sebagai Bahan Bantu Mengajar (BBM) kerana pada masa kini negara dalam proses melahirkan murid yang berfikiran aras tinggi dan mempunyai komunikasi tanpa sempadan. Melalui penggunaan aplikasi TMK, murid meneroka dengan lebih cepat malah lebih cepat berbanding seorang guru.

"Saya menyokong 200 peratus penggunaan Story Map GIS sebagai BBM. Kita nak melahirkan pelajar yang berfikir aras tinggi dan tanpa sempadan. Kalau guna ICT, mungkin murid meneroka lebih cepat daripada kita"

Informan Guru AR

Manakala Informan Cikgu NB berpendapat Story Map GIS merupakan aplikasi yang sesuai untuk dijadikan BBM kerana aplikasi ini dapat menghidupkan sesuatu peristiwa. Peristiwaperistiwa ini dihidupkan secara jelas dengan pelbagai elemen seperti peta, video dan petikanpetikan berkaitan peristiwa sejarah yang dihasilkan di dalam Story Map GIS walaupun murid tidak wujud semasa peristiwa sejarah itu berlaku. Murid dapat menggambarkan situasi berlakunya sesuatu peristiwa, tokoh yang berperanan ketika peristiwa itu berlaku, waktu berlakunya peristiwa tersebut dan mereka lebih mudah memahami dan mengingati peristiwa sejarah tersebut kerana minda murid telah membentuk imej dan sekaligus mengumpulkan data sejarah berkaitan. Guru hanya perlu memperkaya sedikit lagi maklumat yang mereka peroleh melalui aktiviti yang dilakukan melalui aplikasi Story Map GIS supaya murid dapat memahami secara keseluruhan sesuatu peristiwa secara positif.

"Saya rasa memang sangat sesuai sebab Story Map GIS itu menghidupkan peristiwa. Aplikasi ini menghidupkan peristiwa itu secara jelas dengan pelbagai elemen. Peta, video, petikan-petikan. Dia hidup dalam situasi yang murid tidak pernah wujud lagi. Murid boleh gambarkan situasi itu dalam minda mereka pada situasi yang mereka tidak ada. Cikgu cuma perlu tolak sedikit naik ke atas supaya murid memahami secara keseluruhan peristiwa itu secara positif."

Informan Guru NB

Informan P daripada Kumpulan Wawancara Terfokus D pula berpandangan bahawa dia teruja mempelajari Story Map GIS kerana wujudnya aktiviti pemetaan dan ini dianggap menarik kerana dia tidak pernah melakukan perkara sedemikian semasa sesi PdP. 
"Saya rasa teruja sebab ada peta-peta dan itu menarik kerana saya tidak pernah buat macam ni"

Informan P

Dalam perbincangan Kumpulan Berfokus B, mereka merasakan bahawa aplikasi Story Map GIS sesuai untk pembelajaran Sejarah. Ini kerana mereka dapat lebih memahami sejarah yang dipelajari. Mereka juga berpandangan, kaedah pembelajaran yang biasa iaitu melalui membaca, mereka kurang faham tetapi dengan menggunakan aplikasi Story Map GIS ini mereka dapat mengingat fakta dengan lebih baik kerana mereka boleh menonton peristiwa sejarah tersebut melalui video yang dimasukkan ke dalam aplikasi tersebut. Informan D pula berpandangan bahawa dia dapat membuat gambaran sejarah apabila menggunakan aplikasi Story Map GIS. Informan I pula berpendapat, dia dapat mengingat fakta sejarah apabila menonton video di dalam Story Map GIS. Dia juga berpandangan murid dapat membuat eksplorasi lokasi-lokasi sejarah menggunakan aplikasi ini dan ini lebih mudah untuk mereka memahami sesuatu peristiwa sejarah itu.

"Sesuai untuk belajar sejarah" Infoman I

"Lebih faham sejarah. Kalau kita belajar baca je kita tak faham. Kalau kita guna Story Map GIS, kita boleh ingat fakta lebih baik. Boleh tengok video yang ada" Infoman B

“Kita boleh ‘imagine’ sejarah kalau guna Story Map GIS” Informan D.

"Kita boleh ingat fakta sejarah bila kita tengok video dalam Story Map GIS. Kita 'explore' tempat sejarah tu guna Story Map GIS jadi lebih mudah faham" Infoman I

Kumpulan Wawancara Berfokus B

Menurut ahli Kumpulan Wawancara Terfokus C, mereka lebih ingat kerana melalui proses memasukkan data ke dalam Story Map GIS, mereka perlu mencari maklumat dari pelbagai sumber, memilih maklumat sesuai untuk dimasukkan ke dalam Story Map GIS, memasukkan maklumat ke dalam Story Map GIS dan akhirnya mengedit maklumat di dalam Story Map GIS dan proses ini berulang-ulang menyebabkan murid dapat mengingati sesuatu peristiwa sejarah itu dengan lebih baik dan lama. Proses ini memberi kesan terhadap daya ingatan jangka panjang murid terhadap maklumat yang yang di simpan di dalam Story Map GIS. Proses memasukkan data ke dalam aplikasi Story Map GIS memerlukan murid untuk memahami isi kandungan pelajaran sejarah tersebut terlebih dahulu dirumuskan dan barulah disusun ke dalam Story Map GIS yang akhirnya memberi ingatan kekal terhadap maklumat tersebut.

"Lebih ingat sebab banyak kali tengok, lepas tu kita kena buat sendiri” Infoman K

"Banyak kali kena baca sebelum buat" Infoman G

"Bahan kita cari sendiri jadi kita lebih ingat" Infoman F

“Cari sendiri pulak tu” Informan K

“Kita kena baca, pendek-pendekkan untuk bagi orang faham” Infoman F 


\title{
"Kita kena faham sendiri dulu" Infoman G \\ "Kita kena faham dulu" Infoman M \\ "Sebelum kita ringkaskan" Infoman K
}

\author{
Kumpulan Wawancara Berfokus C
}

\section{ii. Aspek emosi (negatif)}

Walau bagaimanapun pada awal penerokaan ada segelintir kecil dalam kalangan murid yang beranggapan ia adalah aplikasi yang susah dan mereka merasa kabur untuk mengaplikasikannya sehinggalah diberi tunjuk ajar dan dengan membuat rujukan terhadap manual yang diberikan kepada mereka. Walau bagaimanapun pada akhir bengkel yang dijalankan didapati majoriti daripada murid berminat menggunakan aplikasi ini. Ini dapat dilihat melalui pemerhatian aktiviti murid sewaktu bengkel dijalankan di salah sebuah sekolah yang dikaji.

"Saya susahlah sebab saya tak pandai nak guna tapi lepas dah 'explore' tu baru pandai sikit-sikit" Infoman N

"Pada saya, saya suka ni sebab dia memudahkan kita mengingat sebab ada video, macam-macam yang kita boleh buat dalam Story Map GIS yang memudahkan pelajar untuk mengingat apa-apa yang dipelajari terutama peristiwa sejarah yang berlaku" Infoman O.

\section{Kumpulan Wawancara Berfokus F}

Kajian ini mendapati bahawa guru dan murid mempunyai pandangan yang positif terhadap penggunaan aplikasi Story Map GIS seperti aplikasi ini mesra pengguna, menarik dan sesuai untuk dijadikan BBM mata pelajaran sejarah. Murid merasa teruja dan berminat terhadap aplikasi ini walaupun pada awalnya ada dalam kalangan mereka merasa aplikasi ini sukar dan kabur ketika cuba membuat Story Map GIS pada awal perbengkelan. Dapatan kajian ini konsisten dengan kajian-kajian sebelumnya berkaitan persepsi murid dan guru terhadap Story Map GIS. Story Map GIS secara fizikalnya menarik perhatian informan iaitu murid-murid dan guru-guru seperti Story Map GIS memaparkan layar-layar yang berwarna-warni, merupakan aplikasi yang mesra pengguna, dapat menyampaikan banyak maklumat, aplikasi yang sistematik, sangat sesuai untuk mata pelajaran sejarah dan penggunaan Story Map GIS dapat mengurangkan penggunaan kertas.

Selain daripada aspek fizikal informan juga mempunyai pandangan berkaitan emosi semasa menggunakan aplikasi Story Map GIS. Antara dapatan kajian berkaitan persepsi terhadap emosi informan semasa menggunakan aplikasi Story Map GIS mendapati bahawa Story Map GIS membantu mereka untuk mudah mengingat fakta atau kronologi sesuatu peristiwa sejarah, ia juga menyeronokkan dan tidak mengantuk ketika PdP dijalankan berbanding PdP yang mengamalkan kaedah syarahan. Aplikasi ini juga dikatakan dapat menghilangkan tekanan kerana mereka berpeluang untuk meneroka dan tidak hanya dibebankan untuk mengingat fakta sebaliknya proses mencari maklumat itu sendiri secara langsung menjadikan mereka lebih ingat fakta. Mereka juga mudah faham isi kandungan pelajaran yang dipelajari serta teruja mencuba aplikasi Story Map GIS. Walau bagaimanapun pada awal penggunaan aplikasi ini, terdapat 
segelintir informan murid yang merasakan ia sesuatu yang susah kerana mereka kurang pendedahan terhadap TMK dan mereka nampak kabur pada awal perbengkelan tetapi selepas beberapa ketika semua informan murid didapati dapat menguasai aplikasi tersebut.

Semua dapatan kajian ini yang berkaitan pandangan murid dan guru terhadap aplikasi Story Map GIS adalah konsisten dengan dapatan kajian lain yang dijalankan di sekolah di mana kajian mendapati bahawa Story Map GIS merupakan suatu aplikasi yang menarik untuk digunakan dan dapat membantu murid untuk memahami suatu peristiwa sejarah serta murid mudah mengingat peristiwa tersebut dan ingatan tersebut lebih lama. Kajian Strachan (2014) turut mendapati Story Map GIS dapat menarik minat murid terhadap pelajaran yang dipelajari. Ia membantu mereka untuk membangunkan KBAT apabila mereka meneroka sesuatu sejarah melalui pencarian maklumat-maklumat dari pelbagai sumber. Marta dan Osso (2015) mendapati Story Map GIS mempromosi KBAT murid dengan membantu mereka berimaginasi. Imaginasi melalui visualisasi pula membantu mereka menyelesaikan masalah dan berfikir di luar kotak. Penglibatan murid secara langsung dalam membina Story Map GIS mengasah daya kreativiti mereka dengan cara membina sendiri cerita mereka melalui aplikasi Story Map GIS berdasarkan tugasan yang diberikan guru. Murid menikmati proses berkreativiti, mempelajari kemahiran baharu, dan menghasilkan peta yang boleh diterbitkan di dalam laman web.

Pengalaman positif ini menunjukkan bahawa platform Story Map GIS versatile dan boleh dibentuk menjadi platform pemetaan yang merentasi sains semula jadi, sains sosial, dan kemanusiaan dan sesuai dengan tahap kemahiran dan minat topik dalam kebanyakan mata pelajaran (Warshawsky, 2016). Story Map GIS juga didapati sangat sesuai bagi mata pelajaran sejarah, ini terbukti apabila Alemy et al. (2017) berjaya mencipta naratif sejarah tentang Masyarakat Asli Amerika dan Masyarakat Afrika Amerika menggunakan aplikasi Story Map GIS yang menarik melalui pemetaan lokasi masyarakat tersebut, gambar-gambar yang sesuai dengan naratif, malah video-video berkaitan sejarah masyarakat tersebut dan mencadangkan kepada sejarawan untuk memetakan sejarah menggunakan aplikasi ini. Ini sekali gus mewujudkan suasana pembelajaran sejarah yang menarik kepada murid-murid. Pengetahuan yang mendalam berkaitan sesuatu sejarah akhirnya dapat meningkatkan semangat patriotisme seseorang murid dan sekali gus akan mewujudkan warganegara yang cintakan negara. Cartwright dan Field (2015) mendapati Story Map GIS berupaya untuk memetakan kisah benar seorang tentera Australia iaitu John Hendry Catwright yang menjalankan tugas sehingga ke Turki sekitar tahun 1914 sebagaimana yang dicatatkan di dalam Story Map GIS sehingga kematian beliau di bumi asing tersebut, jauh dari tanah airnya.

Kini, Story Map GIS memberi peluang kepada pelajar sama ada di peringkat sekolah rendah atau sekolah menengah mahupun di institusi pengajian tinggi untuk merasai pengalaman mengaplikasi aplikasi GIS walaupun tidak mempunyai latar belakang pendidikan berkaitan GIS. Penggunaan Story Map GIS sesuai bagi tujuan pembentangan projek, mengasah daya kreativiti mereka menerusi penglibatan semua murid sama ada secara berkumpulan ataupun gerak kerja secara individu (Patterson \& Bickel, 2016; Battersby \& Remington, 2013).

\section{Kesimpulan}

Penggunaan aplikasi Story Map GIS memberi impak positif kepada PdP Sejarah STPM apabila didapati murid dan guru mempunyai persepsi yang positif terhadap aplikasi tersebut sama ada dalam aspek fizikal mahupun aspek emosi semasa menggunakan aplikasi ini. Aktiviti 
mengekplorasi aplikasi Story Map GIS mewujudkan perasaan teruja dan seronok kepada murid dan sekaligus menarik perhatian mereka untuk mendalami kandungan pelajaran yang mereka perlu pelajari. Pemetaan sejarah di dalam Story Map GIS juga menggalakkan murid untuk memahami kronologi sejarah tersebut berdasarkan tempat, masa dan peristiwa yang berlaku ketika itu. Keupayaan murid untuk memahami kronologi sejarah merupakan salah satu daripada Kemahiran Pemikiran Sejarah (KPS) yang perlu diterapkan kepada murid-murid. Pengupayaan kemahiran ini sekaligus akan melahirkan murid-murid yang celik sejarah dan membentuk mereka menjadi generasi yang matang serta lebih patriotik. Ini sejajar dengan dengan salah satu aspirasi murid di dalam Pelan Pembangunan Pendidikan Malaysia (PPPM 2013-2025) iaitu bagi mewujudkan generasi yang memiliki identiti nasional yang memerlukan setiap murid memahami Sejarah Malaysia, berkongsi pengalaman dalam dan luar sekolah, dan berkongsi aspirasi untuk masa depan Malaysia. Walau bagaimanapun terdapat beberapa kekangan dalam melaksanakan Story Map GIS di sekolah di dalam kajian ini seperti masa yang singkat untuk pengaplikasian aplikasi ini dan kemudahan akses internet yang agak terhad di kawasan sekolah.

\section{Rujukan}

Alemy, A., Hudzik, S., \& Matthews, C.N. (2017). Creating a user-friendly interactive interpretive resource with ESRI's ArcGIS Story Map Program. Historical Archaeology, 51(2), 288-297. Retrieved from https://doi.org/10.1007/s41636-017-0013-7

Ang Kean Hua (2015). Sistem Informasi Geografi (GIS): Pengenalan kepada perspektif komputer. Geografia-Malaysian Journal of Society and Space, 11(1), 24-31.

Ayu, D. (2018). Tiga versi cerita Panji: Kajian Naratologi Menurut Perspektif A.J Kreimas. Master's thesis, Universitas Sanata Dharma, Yogyakarta, Indonesia. Retrieved from http://repository.usd.ac.id/31028/2/144114017_full.pdf

Battersby, S. E., \& Remington, K.C. (2013, Spring). Story Maps in the classroom. ArcUser, 6265. Retrieved from https://www.esri.com/about/newsroom/wp-content/uploads/2018/11/ storymaps.pdf

Berendsen, M., Hamerlinck, J., \& Webster, G. (2018). digital story mapping to advance educational atlas design and enable student engagement. ISPRS International Journal of Geo-Information, 7(3), 125. Retrieved from https://doi.org/10.3390/ijgi7030125

Cartwright, W., \& Field, K. (2015, August). Exploring cartographic storytelling. Reflections on mapping real-life and fictional stories. In Proceedings of the International Cartographic Conference, Rio de Janeiro, Brazil (pp. 23-28).

Cope, M.P., Mikhailova, E.A., Post, C.J., Schlautman, M.A., \& Carbajales-Dale, P. (2018). Developing and evaluating an ESRI Story Map as an educational tool. Natural Sciences Education, 47(1), 1-9. Retrieved from https://doi.org/10.4195/nse2018.04.0008

Coskie, T., Trudel, H., \& Vohs, R. (2010). Creating community through storytelling. Talking Points, 22(1), 2-9.

Dahlstrom, M.F. (2014). Using narratives and storytelling to communicate science with nonexpert audiences. Proceedings of the National Academy of Sciences, 111(Supplement 4), 13614-13620.

Dewey, J. (1933). Philosophy and Civilization. Philosophy, 8(31), 360-361.

Edmondson, D. (2018). Regionalization: A Story Map lesson on regions. Geography Teacher, 15(1), 36-38. Retrieved from https://doi.org/10.1080/19338341.2017.1413001 
Kallaher, A., \& Gamble, A. (2017). GIS and the humanities: Presenting a path to digital scholarship with the Story Map app. College and Undergraduate Libraries, 24(2-4), 559573. Retrieved from https://doi.org/10.1080/10691316.2017.1327386

Kerski, J. (2013). Understanding our changing world through web-mapping based investigations. J-Reading - Journal Of Research And Didactics In Geography, 2(2), 11-26. Retrieved from http://www.j-reading.org/index.php/geography/article/view/39

Kirkby, J., Faulkner, J., \& Perrin, J. (2014). 'Once there was a...': Reclaiming storytelling in the middle years. Literacy Learning: The Middle Years, 22(2), 1-10.

Lateh, H., \& Muniandy, V. (2011). GIS dalam pendidikan geografi di Malaysia: Cabaran dan potensi. Geografia-Malaysian Journal of Society and Space, 7(1), 42-52.

Magli, G. (2018). From symbols to written landscapes. The role of astronomy in ancient Egyptian architecture. Lebenswelt. Aesthetics and philosophy of experience, (11), 125-133.

Marta, M., \& Osso, P. (2015). Story Maps at school: teaching and learning stories with maps. $J$ Reading - Journal Of Research And Didactics In Geography, O(2), 61-68. Retrieved from https://doi.org/10.4458/6063-05

Patterson, J., \& Bickel, A. (2016, September). Communicating local relevance of ocean observations: Integrating real-time ocean sensor data visualizations, online communications, and ocean issues to engage public audiences. In OCEANS 2016 MTS/IEEE Monterey (pp. 1-4). IEEE.

Strachan, C. (2014). Teachers' Perceptions of Esri Story Maps as Effective Teaching Tools. Master's thesis, University of South Carolina, Columbia, United State. Retrieved from https://scholarcommons.sc.edu/etd/2907

Tapscott, D. (2008). Grown up digital. Boston: McGraw-Hill Education.

Tjandra, S.A., Pranayama, A., \& Sutanto, R. (2017). Perancangan concept art berdasarkan sejarah Kerajaan Majapahit. Jurnal DKV Adiwarna, 1(10), 12.

Warshawsky, D.N. (2016). Teaching GIS in the classroom: Story Maps as a case study. In D. J. Cowen, (Ed.), STEM and GIS in Higher Education (pp. 187-195). California, USA: ESRI. Retrieved from https://esri.app.box.com/v/STEMGIS

Wayne, C.B. (1978). The modern language review, 73(1), 144-151. Retrieved from https://doi.org/10.2307/3728156 